\title{
Mining
}

\section{Use of depressants in the direct flotation of a silicate-carbonate phosphate ore}

\author{
Uso de depressores na flotação direta de um \\ fosfato sílico-carbonatado
}

\begin{abstract}
Adalberto Leles de Souza
Centro de Desenvolvimento da Tecnologia Nuclear Belo Horizonte- Minas Gerais - Brasil

adalbertoleles@yahoo.com.br
\end{abstract}

\section{Rodrigo Oscar de Albuquerque}

Centro de Desenvolvimento da Tecnologia Nuclear Belo Horizonte- Minas Gerais - Brasil

roda@cdtn.br

Fernando Soares Lameiras

Centro de Desenvolvimento da Tecnologia Nuclear Belo Horizonte- Minas Gerais - Brasil

fsl@cdtn.br

Plínio Eduardo Praes

Centro de Desenvolvimento da Tecnologia Nuclear Belo Horizonte- Minas Gerais - Brasil

plinio@cdtn.br

\section{Antônio Eduardo Clark Peres}

Departamento de Engenharia Metalúrgica e de Materiais/Escola de Engenharia Universidade

Federal de Minas Gerais

Belo Horizonte- Minas Gerais - Brasil

aecperes@demet.ufmg.br

\begin{abstract}
A high demand for mineral resources observed in recent decades has led to an expansion in production in the mining industry. Different process alternatives have been proposed for selective separation between apatite and contaminants (carbonates and silicates) present in phosphate ores. Magnetic separation, calcination and gravity separation processes are methods that present low efficiency and high cost. Flotation is the most common process; however the selectivity is hampered by the superficial similarity of the chemical composition of phosphates and carbonates, high surface activity of the collectors used, interactions between dissolved ionic species of certain mineral with another and also interactions between dissolved ionic species and reagents. In this study, conducted in a laboratory scale, eight different depressants, organic and inorganic, were tested in the direct flotation of a Brazilian silicate-carbonate phosphate ore. The best performance in the depression of calcite and silicates was achieved with cassava starch.
\end{abstract}

Keywords: flotation depressants; anionic flotation; silicate-carbonate phosphate ore

\section{Resumo}

A forte demanda por bens minerais verificada nas últimas décadas tem levado o setor mineral a ampliar sua capacidade produtiva. Diferentes métodos de concentração têm sido propostos para separação seletiva da apatita dos contaminantes carbonatos e silicatos presentes em minérios fosfáticos. Separação magnética, hidrogravimétrica e calcinação são métodos que apresentam baixa eficiência e custo elevado. A flotação é o método mais indicado, porém a seletividade é dificultada devido à similaridade da composição química superficial entre fosfatos e carbonatos, a alta atividade superficial dos coletores utilizados, interações entre espécies iônicas dissolvidas de um mineral sobre outro e, também, entre espécies iônicas dissolvidas e reagentes. Nesse estudo, realizado em laboratório, oito diferentes depressores, orgânicos e inorgânicos, foram testados na flotação aniônica direta de um fosfato sílico-carbonatado. O melhor desempenho foi obtido com fécula de mandioca, que exerceu boa depressão sobre a calcita e os silicatos.

Palavras chave: Flotação; depressores; fosfato sílico-carbonatado. 


\section{Introduction}

Flotation is the most common concentration process used by the mineral industry, both in quantity of ores processed and in diversity of applications (Peres et al, 2007). At present, over $2 \times 10^{9} \mathrm{t}$ per year of ore is estimated to be processed through flotation. In Brazil, this technique played an important role in the growth of the mineral sector, especially in the industry of fertilizers. Different typologies of phosphates are concentrated through this process.

Ores presenting complex mineralogical associations, such as the Brazilian phosphates bearing silicates and carbonates in the gangue, correspond to a significant fraction of the local reserves and present poor response to concentration via flotation or even lack of a process route for economical recovery (Albuquerque, 2010). The main phosphate reserves in Brazil, such as the ones located in the state of Minas Gerais (Araxá and Tapira) and the ones in Goiás (Catalão), as well as the uranium phosphate of the Santa Quitéria reserve in the state of Ceará present this typology (Oliveira, 2007).

The world challenge encountered by the phosphate industry is the development of a process route leading to the concentration of silicate-carbonate ores. For igneous as well as sedimentary deposits, this achievement would lead to a better economical use and consequently longer lifespan of the mines or it would even make new ventures available. In particular, in the Brazilian case, an improvement would lead to a significant

\section{Materials and methods}

The ore used in this study was provided by the Centro de Desenvolvimento da Tecnologia Nuclear (CDTN/CNEN), in Belo Horizonte (MG). The chemical determinations of $\mathrm{P}_{2} \mathrm{O}_{5}$ and $\mathrm{SiO}_{2}$ were carried out with the use of an X-ray fluorescence spectrophotometer (EDX-720, Shimadzu), whereas the determination for $\mathrm{CaCO}_{3}$ was done via calcination. The size characterization was performed through combined sieving (Tyler series) and the Sympatec Helos particle analyser. The mineralogical characterization was carried out through the powder method, with the use of an X-ray difratometer - model Geigerflex, semi-automatic made by Rigaku. increase in the mining reserves, and consequently a reduction in the import of phosphate fertilizers.

Amongst the procedures described by Hanna and Somasundaran (1976) to obtain selectivity in the separation between sparingly soluble minerals, as well as in the separation apatite/carbonates (calcite/dolomite), the use of depressants is uppermost. These modifiers are responsible for inhibiting the absorption of the collector over the surfaces of the minerals whose flotation is not desired, thus keeping the necessary hydrofilicity so that the particles get in contact with the aqueous phase. Prasad (1992) defines the depressants as reagents which improve the interaction of the mineral surfaces where flotation is not desired with the molecules of water, thus preventing the adsorption of collectors.

Since the separation between sparingly soluble minerals is complex, especially when the minerals involved contain similar terrous-alkaline cations, modifiers are steadily used to produce selectivity. Amongst various examples cited in technical literature are organic depressants, (non-modified and modified starches, guar gum, carboxymethylcellulose and tannins); inorganic depressants (sodium silicate, sodium sulphate, polyphosphates, dicromates, fluorates, and certain inorganic acids); $\mathrm{pH}$ regulators and modulators of the ionic composition of the pulp. The organic depressants present various advantages over the inorganic ones, for they are biodegradable, more stable, atoxic and usually less expensive (Liu et al, 2000).

Hanna and Somasundaran (1976) attribute four main effects of the modifiers to the flotation of the sparingly soluble minerals: (i) direct effect on the property of minerals, such as adsorption capability and zeta potential; (ii) reduction of adsorption of the collector over the surface covered by the layer of the modifier; (iii) effect on the chemical composition of the pulp; (iv) effect on the foaming (frothing) process.

Prasad (1992), referring specifically to the organic depressants, stated that their adsorption mechanisms onto mineral surfaces include electrostatic interaction, hydrogen bonds, formation of metal-depressant complexes, covalent bonds and even self-activation of the mineral. Nunes and Peres (2011), in a recent review addressing carbonate depressants, showed that the organic agents have a sufficient number of highly hydrophilic polar groups in their structure, such as - $\mathrm{OH}$ e - $\mathrm{COOH}$, which orient themselves towards the aqueous phase, rendering the adsorbate hydrophilic. They indicate starch as the best depressant for ores presenting high contents of calcite and carboxymethylcellulose for ores containing dolomite.

This work, carried out with a silicate-carbonate phosphate ore, aimed at studying the performance of depressant agents of different origins in the separation of apatite from the contaminants calcite and silicates by laboratory scale flotation.
The batch flotation tests were carried out in a laboratory using a mechanical cell Darma, Model D-1, Sub-A, provided with a mechanical froth scrapper for the removal of the floated material and a bucket with a $3.0 \mathrm{~L}$ capacity. Coconut oil was used as collector (Liacid 1218, fatty acid supplied by Miracena-Nuodex, dosage $700 \mathrm{~g} / \mathrm{t}$ ) and the frother Flotanol D25 (ether polyalkyleneglycol, manufactured by Clariant S/A, dosage $30 \mathrm{~g} / \mathrm{t}$ ), whose dosages were adjusted in preliminary tests and kept constant in this study. The $\mathrm{pH}$ value used was 10.0, adjusted with sodium hydroxide. The depressants, inorganic and organic, tested with dosages ranging from
100 to $600 \mathrm{~g} / \mathrm{t}$, were: i) sodiumhexametaphosphate;

ii) sodium silicate;

iii) corn starch (Flotamil 75, nonmodified starch by Caramuru);

iv) cassava starch (Amilogill 1500, non-modified starch, supplied by Cargill);

v) modified starch I (Filmplus ${ }^{\circledR}$ 9002 ACC, cationic starch, supplied by Cargill);

vi) modified starch II (EP2031, cationic starch, supplied by Cargill);

vii)dextrin (modified starch, supplied by Cargill); and

viii) CMC (carboxymethylcellulose, supplied by Pietschemical). 
With exception of dextrin, all starches and CMC were gelatinized with $\mathrm{NaOH}$. The inorganic reagents were diluted as solutions in the required concentrations.

Depressant and collector conditioning times were, 5.0 and 3.0 minutes, respectively, and the flotation time was 5.0 minutes. These levels were kept constant

\section{Results and discussion}

\section{1 - Characterization of the sample}

Figure 1 represents the head sample particle size distribution. It shows that $2.9 \%$ of the material is retained in 210 $\mu \mathrm{m}$ and $32.7 \%$ passing in $37 \mu \mathrm{m}$, adequate for a high liberation degree of in all the tests.

It is worth pointing out that the modified starch I and II are produced with the introduction of positive charges in its molecules by means of a cationizing reaction with the use of reagents containing imine, amine, ammonium and sulphonium groups, being the degree of substitution the parameter that tells them apart (Bertolini, 2010). On the other hand, dextrin is obtained by means of a treatment which breaks and reverses the molecular chain of the starches by enzymatic or thermal degradation under acid conditions (Leja, 1982). According to the manufacturers, the amylopectin content in the cassava and corn starch are 83 and $74 \%$, respectively.

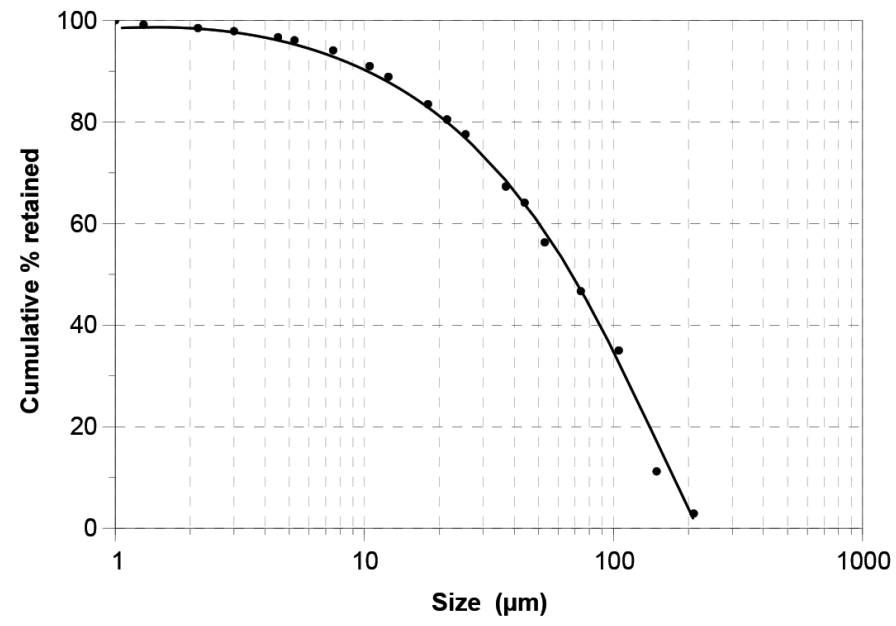

\begin{tabular}{c|c}
\hline Species & Grade (\%) \\
\hline $\mathrm{P}_{2} \mathrm{O}_{5}$ & 17.20 \\
$\mathrm{CaO}$ total & 25.70 \\
$\mathrm{CaCO}_{3}$ & 20.50 \\
$\mathrm{SiO}_{2}$ & 21.90 \\
$\mathrm{Fe}_{2} \mathrm{O}_{3}$ & 3.89 \\
$\mathrm{Al}_{2} \mathrm{O}_{3}$ & 7.81 \\
$\mathrm{MgO}$ & 1.12 \\
\hline
\end{tabular}

$21.9 \%$, respectively. In terms of mineralogy, the sample is made up of apatite and by the contaminants calcite and silicates (albite, quartz, biotite, flogopite, montimorillonite, vermiculite, and amfiboles).
Figure 1

Head sample size distribution.

\section{2 - Flotation tests}

Figure 2 presents the results of the grade of $\mathrm{P}_{2} \mathrm{O}_{5}$ obtained in the concentrates of apatite as a function of the variation of the dosage of the various depressant agents. It is shown that concentrates with $\mathrm{P}_{2} \mathrm{O}_{5}$ content at $30 \%$ were only obtained with the high dosage tested of the depressant cassava starch (400 $\mathrm{g} / \mathrm{t}$ ) or corn starch $(600 \mathrm{~g} / \mathrm{t})$, both non modified starches. On the other hand, the worst performances were observed when CMC, cationic starch I, cationic starch II, dextrin, and sodium silicate were employed.

The results of the recovery of $\mathrm{P}_{2} \mathrm{O}_{5}$ obtained in the concentrates of apatite as a function of the dosage of the depressants tested are presented in Figure 3. Usually, what is observed is the fact that the increase in the dosage of depres- sant results in a reduction of recovery of $\mathrm{P}_{2} \mathrm{O}_{5}$. CMC was the agent which produced concentrates with the highest levels of recovery, reaching $83 \%$, whereas dextrin presented the worst results. With cassava starch and corn starch, agents that yielded concentrates having the highest grades of $\mathrm{P}_{2} \mathrm{O}_{5}$, the recovery presented intermediate values, between $61 \%$ and $79 \%$. 
Figure 2

$\mathrm{P}_{2} \mathrm{O}_{5}$ grade as a function of the dosage of the different depressants.

Figure 3 $\mathrm{P}_{2} \mathrm{O}_{5}$ recovery as a function of the dosage of the different depressants.

Figure 4

$\mathrm{CaCO}_{3}$ grade as a function of the dosage of the different depressants.

Figure 4 depicts the results of the contents of the contaminant $\mathrm{CaCO}_{3}$ obtained in the apatite concentrates as a function of the variation of the dosage of depressants. One can see that concentrates having contents below $15 \%$ were only achieved with a higher dosage of more selective depressants: cassava and corn starch. The best performance was achieved at $400 \mathrm{~g} / \mathrm{t}$ of cassava starch, which generated a concentrate with a $\mathrm{P}_{2} \mathrm{O}_{5}$ grade of $30.8 \%$ and grades of the
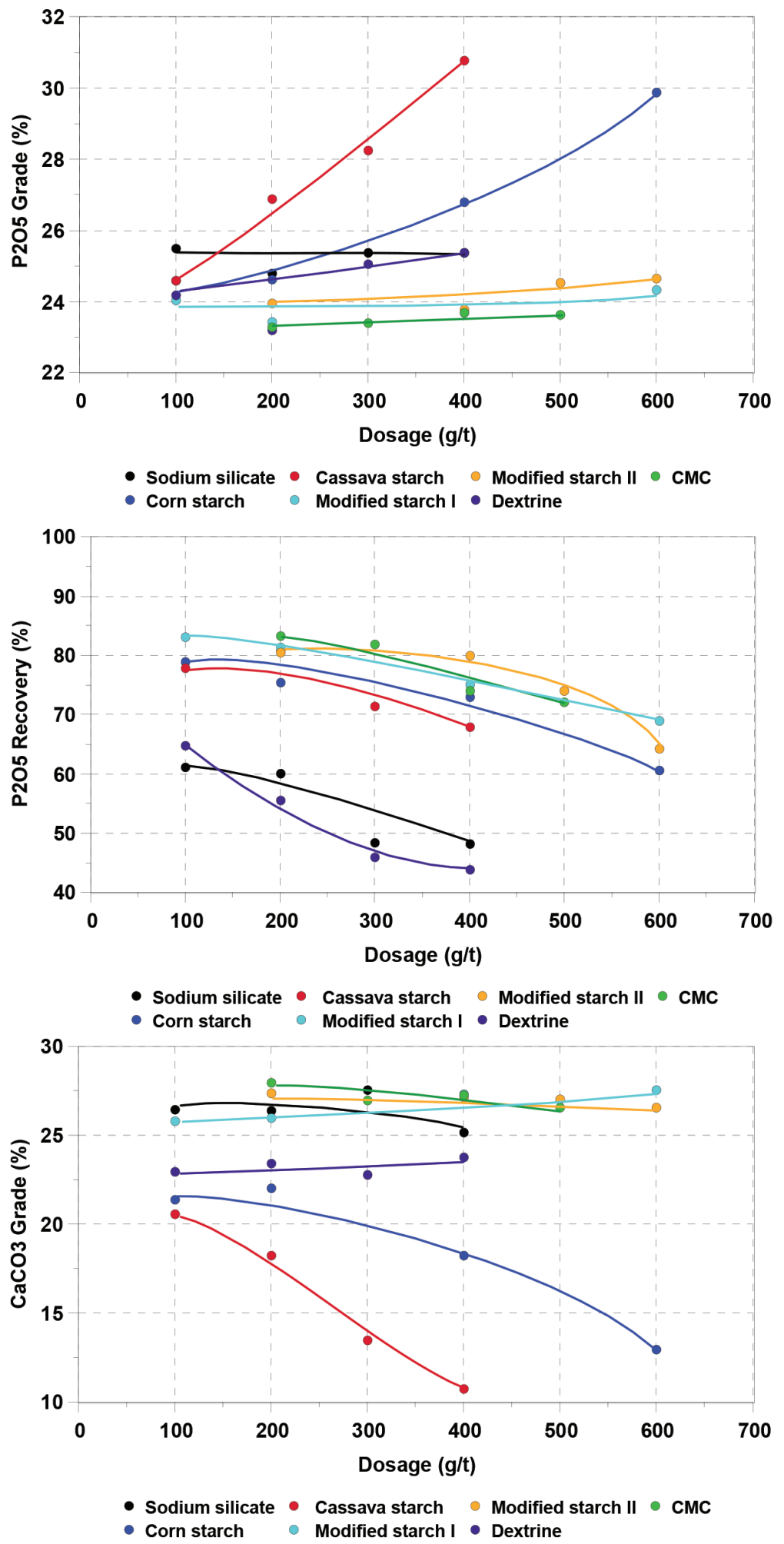

contaminants $\mathrm{CaCO}_{3}$ and $\mathrm{SiO}_{2}$ of 10.8 and $7.8 \%$, respectively. Under this condition, the recovery of $\mathrm{P}_{2} \mathrm{O}_{5}$ reached $68 \%$.

Figure 5 depicts the grade of the contaminant $\mathrm{SiO}_{2}$ obtained in the concentrates of apatite as a function of the dosage of the depressants. It can be noted that, in general, all the depressants studied perform well as far as the depression of silicate minerals present in the sample is concerned, thus yielding concentrates with the $\mathrm{SiO}_{2}$ content ranging from $6.2 \%$ to $8.5 \%$. A good depressant activity of dextrin and sodium silicate is noticeable. Conversely, the CMC was the reagent which presented the worst performance.

It is worth mentioning that the inorganic depressant sodium hexametaphosphate, amongst all the depressants investigated, was the one which presented the worst performance, proving incapable of yielding selectivity between apatite and the mineral contaminants under the conditions investigated. 
Confirming Nunes and Peres (2011), which presented starch as an efficient depressant for calcite, in the present study, cassava starch and corn starch were the most efficient agents, leading

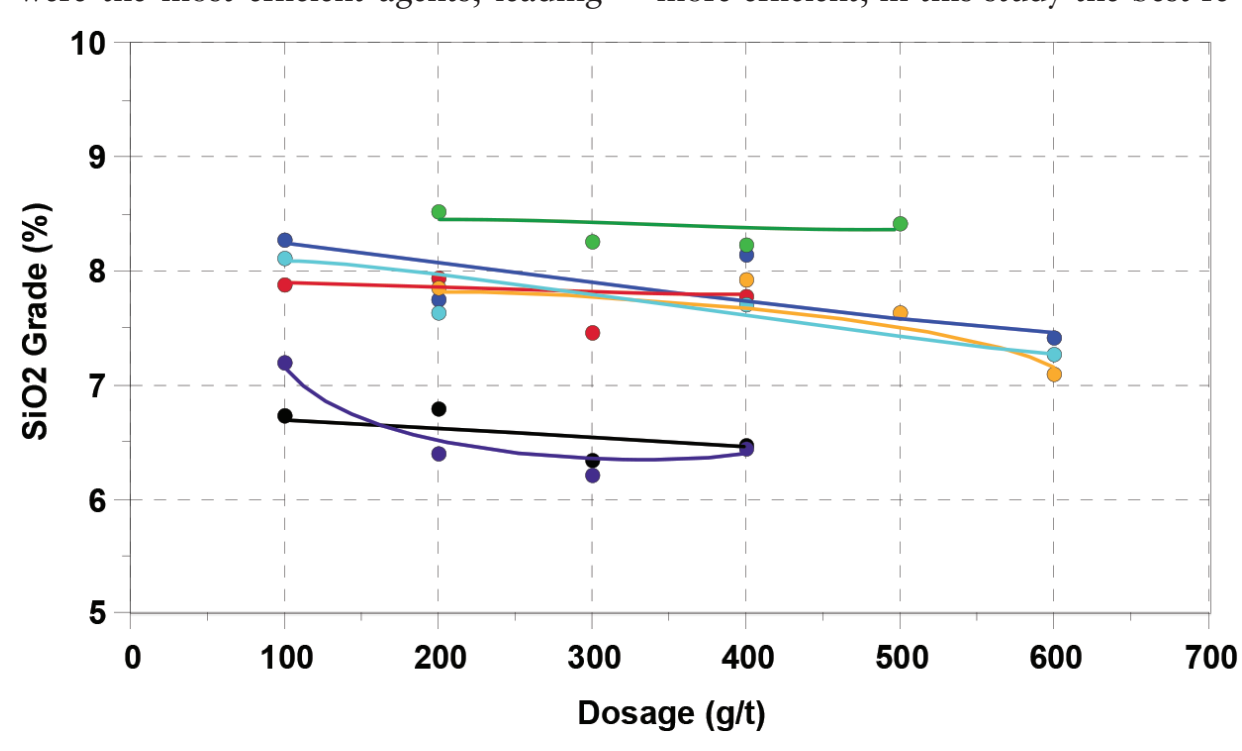

- Sodium silicate - Cassava starch $\bullet$ Modified starch II $\bullet$ CMC

- Corn starch $\bigcirc$ Modified starch I - Dextrine

\section{Conclusions}

The results of this study led to the following conclusions:

- Amongst all the depressants investigated, sodium hexametaphosphate was the one which presented the worst performance, not being able to provide good selectivity;

- The modified starches and carboxymethylcellulose presented low selectivity and were not able to reduce the contents of the contaminants in the to good selectivity. Also to confirm the results presented by Araujo (1988), which showed that a starch based depressant with a higher amylopectin content is more efficient; in this study the best re- sults obtained were with cassava starch (83\% of amylopectin) when compared with corn starch (74\% of amylopectin), depressing mainly the contaminant calcite.
Figure 5

$\mathrm{SiO}_{2}$ grade as a function of the dosage of the different depressants.

\section{Acknowledgements}

The authors of this paper should like to thank the Department of concentrate;

- The non-modified starches (cassava and corn) were the most efficient depressants, providing good selectivity mainly for the contaminant calcite;

- Cassava starch, possibly for its higher content of amylopectin, proved to be more efficient than corn starch;

- In order to reach similar per- formance, the dosage of cassava starch was significantly lower than that of corn starch; and

- At $400 \mathrm{~g} / \mathrm{t}$ of cassava starch, a concentrate was obtained with grade and recovery of $\mathrm{P}_{2} \mathrm{O}_{5}$ of $30.8 \%$ and $68 \%$, with contaminant grades $\mathrm{CaCO}_{3}$ and $\mathrm{SiO}_{2}$ of $10.8 \%$ and $7.8 \%$, respectively.

\section{References}

Mineral Technology of CDTN/CNEN for invaluable contribution towards the conclusion of this work.

ALBUQUERQUE, R.O. Process alternatives for the flotation of the Itataia's phosphorous-uraniferous ore. CPGEM/UFMG, 2010. 201 p. (Ph.D. Thesis)

ARAUJO, A. C. Starch modification of the flocculation and flotation of apatite. Vancouver - Canada: Departament of Mining and Mineral Process Engineering, University of British Columbia, 1988. (Ph.D. Thesis).

BERTOLINI, A. C. Starches: characterization, properties, and applications. Taylor and Francis Group, 2010.

HANNA, H. S., SOMASUNDARAN, P. Flotation of salt-type minerals. In: FUERSTENAU, M. C. (ed.). Flotation A. M. Gaudin Memorial Volume. Baltimore: AIME, vol. 1, p. 197-272, 1976.

LEJA, J. Flotation surfactants. In: Surface Chemistry of Froth Flotation. New York: Plenum Press, 1982. cap. 5., p. 205-333.

LIU, Q., Zhang, Y., Laskowski, J. S. The adsorption of polysaccharides onto mineral surfaces: an acid/base interaction. International Journal of Mineral Processing, v. 60, p. 229-245, 2000. Disponível em: < http://www.scopus.com/inward/record.url?eid=2- 
-s2.0-0034562628\&partnerID=40\&md5=3d2afa60b4b75a 370a $228 f 56569811$ bc >

NUNES, A. P. L., Peres, A. E. C. Carbonates depressant reagents - a review. Tecnologia Mineral, CETEM, vol. 1, p. 1-47, 2011.

OLIVEIRA, M. S. Silicate-carbonate phosphate ore: fundamental study. CPGEM/ UFMG, 2007. 207 p. (Ph.D. Thesis).

PERES, A. E. C. et al. Non-sulfide minerals plant practice. In: FUERSTENAU, M. C., JAMESON, G., YOON, R. H. Froth flotation: a century of innovation, SME, Colorado, cap. 5, p. 845-868, 2007.

PRASAD, M. S. Reagents in the mineral industry - recent trends and applications. Minerals Engineering, v.5, n. 3-5, p. 279-294, 1992. DOI: 10.1016/08926875(92)90211-Q

Received: 02 de June 2013 - Accepted: 20 de February 2014. 